\title{
Molecular mechanisms underlying neuroepithelial/ependymal denudation in the hydrocephalic hyh mutant: spatial and temporal expression of alpha-SNAP and $\mathbf{N}$-cadherin Luis Federico Bátiz*, Cristian Oliver, Mauro Alvarez, Sara Rodríguez and Esteban M Rodríguez
}

Address: Instituto de Histología y Patología, Universidad Austral de Chile, Valdivia, Chile

Email: Luis Federico Bátiz* - federicobatiz@uach.cl

* Corresponding author

from 50th Annual Meeting of the Society for Research into Hydrocephalus and Spina Bifida

Cambridge, UK. 30 August - 2 September 2006

Published: 21 December 2006

Cerebrospinal Fluid Research 2006, 3(SuppI I):SI6 doi:I0.II86/I743-8454-3-SI-SI6

C 2006 Bátiz et al; licensee BioMed Central Ltd.

\section{Background}

The hyh mutant mouse develops fetal-onset neuroepithelial/ependymal denudation that precedes cerebral aqueduct obliteration and hydrocephalus $[1,2]$. A hypomorphic point mutation (M105I) in alpha-SNAP protein has been identified as responsible of the hyh phenotype [3]. Alpha-SNAP is widely distributed in all mammalian tissues and cell types [4]. It is a key component of the SNARE machinery for membrane fusion and participates at different levels of vesicular traffic of proteins, including transport to plasma membrane [5]. But, why does a mutation in such an ubiquitous protein lead to selective developmental disorders of the central nervous system? How is alpha-SNAP mutation involved in neuroepithelial/ependymal denudation? Considering that (i) the pattern of ependymal denudation matches that of ependymal differentiation [1], and (ii) the ependyma of circumventricular organs, endowed with a special set of junctions, never detach; it is proposed that alpha-SNAP mutation could result in a failure in the adhesion/junction proteins physiology during brain development leading to neuroepithelial/ependymal denudation. The aim of the present investigation was two fold: (a) to study the temporal and spatial expression of alpha-SNAP, NSF, and some proteins involved in intercellular junctions, and (b) to evaluate the importance of these proteins on ependymal physiology and stability.

\section{Materials and methods}

(i) Brain samples of non-hydrocephalic (wild type) and hydrocephalic (mutant) mice from the hyh strain (B6C3Fe-a/a-hyh) were studied by immunocytochemistry (IMC) and transmission electron microscopy (TEM) at various developmental stages. Protein homogenates from telencephalum, mesencephalum/brain stem and cerebellum were analyzed by Western blot. The expression levels of mRNA encoding for alpha-SNAP and NSF were analyzed by semi-quantitative PCR. (ii) Ependymal explants obtained from adult bovine Sylvius aqueduct were cultured for 24 hours and used to evaluate the role of adherens junctions and $\mathrm{N}$-cadherin in ependymal stability. Basically, after validation of this ex-vivo model, N-cadherin functional blocking assays in 1DIV explants using specific antibodies and competitive peptides were performed. The effect of $\mathrm{N}$-cadherin blockage was evaluated by light microscopy (quantitative analysis), IMC, and TEM.

\section{Results}

(1) alpha-SNAP and NSF are preferentially expressed in the CNS and at early developmental stages; (2) alphaSNAP is preferentially expressed at ventricular lining; (3) in mutant animals, the decrease of alpha-SNAP protein varies at different stages and at different brain regions; (4) hyh mutant mice present an increase in NSF protein, 
probably due to its overexpression; (5) ependymal cells express N-cadherin but not E-cadherin; (6) different ependymal subpopulations showed a differential expression of alpha-SNAP and N-cadherin; (5) functional blocking of $\mathrm{N}$-cadherin led to (i) changes in $\mathrm{N}$-cadherin immunocytochemical pattern, (ii) ultrastructural modifications of adherens junctions, (iii) increase of the intercellular space, and (iv) detachment of the ependyma leading to large denuded areas of the explants.

\section{Conclusion}

The selective expression of alpha-SNAP in the brain, and its differential expression at distinct brain regions and cell types may contribute to the understanding of the molecular mechanisms underlying hyh phenotype. N-cadherindependent adherens junctions play a key role in ependymal stability. An alteration in the physiology (traffic?) of $\mathrm{N}$-cadherin appears to be the one of the mechanisms operating in the ependymal denudation of hyh mice.

\section{Acknowledgements}

Supported by Grants Fondecyt 1030265, Chile to EMR \& CONICYT and DID, Universidad Austral de Chile, to LFB.

\section{References}

I. Jiménez AJ, Tomé M, Páez P, Wagner C, Rodríguez S, Fernández-Llebrez $P$, Rodríguez EM, Pérez-Fígares JM: A programmed ependymal denudation occurring during the embryonic life precedes the development of congenital hydrocephalus in the mutant mouse hyh. J Neuropathol Exp Neurol 200I, 60:1105-1119.C.

2. Wagner, Bátiz LF, Rodríguez S, Jiménez AJ, Páez P, Tomé M, PérezFígares JM, Rodríguez EM: Cellular mechanisms involved in the stenosis and obliteration of the cerebral aqueduct of hyh mutant mice developing congenital hydrocephalus. I Neuropathol Exp Neurol 2003, 62:1019-1040.

3. Chae TH, Kim S, Marz KE, Hanson PI, Walsh CA: The hyh mutation uncovers roles for alpha Snap in apical protein localization and control of neural cell fate. Nat Genet 2004, 36:264-270.

4. Clary DO, Griff IC, Rothman JE: SNAPs, a family of NSF attachment proteins involved in intracellular membrane fusion in animals and yeast. Cell 1990, 61:709-72I.

5. Stenbeck G: Soluble NSF-attachment proteins. Int J Biochem Cell Biol 1998, 30:573-577.

\section{Publish with Biomed Central and every scientist can read your work free of charge}

"BioMed Central will be the most significant development for disseminating the results of biomedical research in our lifetime. " Sir Paul Nurse, Cancer Research UK

Your research papers will be:

- available free of charge to the entire biomedical community

- peer reviewed and published immediately upon acceptance

- cited in PubMed and archived on PubMed Central

- yours - you keep the copyright

Submit your manuscript here:

http://www.biomedcentral.com/info/publishing_adv.asp 